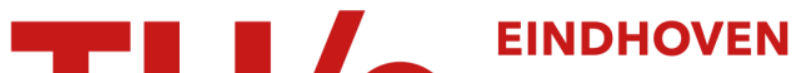 \\ UNIVERSITY OF \\ TECHNOLOGY
}

\section{Setting customer service levels : an overall cost-approach}

\author{
Citation for published version (APA): \\ Konijnendijk, P. A. (1991). Setting customer service levels : an overall cost-approach. International Journal of \\ Production Economics, 23, 139-146.
}

\section{Document status and date:}

Published: 01/01/1991

\section{Document Version:}

Publisher's PDF, also known as Version of Record (includes final page, issue and volume numbers)

\section{Please check the document version of this publication:}

- A submitted manuscript is the version of the article upon submission and before peer-review. There can be important differences between the submitted version and the official published version of record. People interested in the research are advised to contact the author for the final version of the publication, or visit the $\mathrm{DOI}$ to the publisher's website.

- The final author version and the galley proof are versions of the publication after peer review.

- The final published version features the final layout of the paper including the volume, issue and page numbers.

Link to publication

\section{General rights}

Copyright and moral rights for the publications made accessible in the public portal are retained by the authors and/or other copyright owners and it is a condition of accessing publications that users recognise and abide by the legal requirements associated with these rights.

- Users may download and print one copy of any publication from the public portal for the purpose of private study or research.

- You may not further distribute the material or use it for any profit-making activity or commercial gain

- You may freely distribute the URL identifying the publication in the public portal.

If the publication is distributed under the terms of Article $25 \mathrm{fa}$ of the Dutch Copyright Act, indicated by the "Taverne" license above, please follow below link for the End User Agreement:

www.tue.nl/taverne

Take down policy

If you believe that this document breaches copyright please contact us at:

openaccess@tue.nl

providing details and we will investigate your claim. 


\title{
Setting customer service levels: an overall cost-approach
}

\author{
Paul A. Konijnendijk \\ Department of Indusiral Engineering and Management Science Eindhoten Lnufrsm. of Terhmolig!, \\ E.j.dho,en. The Netherlands
}

\begin{abstract}
Customer service level decisions are usually based on qualitative niarket information and internal costs only in this texs we suggest an approach of using quantified costs information of both customer and suppliar in siting serv ce lev ets After a brief introduction on how customer service can be defined we describe its typical cost-structure Due to the characteristics of this cost-structure the use of unquantified and ambiguous market information in selting servce levels can easily

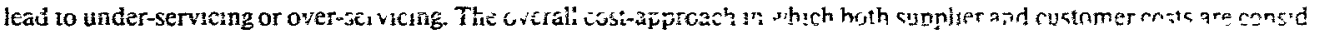
ered better supports service level decisions Th's approach must be used in combination with other senvice level considerations Some conditions for using the approach are identified The applicability of the approach is iescr.bed in relauon to typica ${ }^{1}$ customer-suppher relat onships
\end{abstract}

\section{Introduction}

In the last couple of years many writers have advocated the integration of marketıng and logistics or "customer service" as a new approach towards customers $[1-3]$. Some writers have called it the most important strategy for the nineties [4]. The reason for that lies in several market trends like shorter product life cycles, broader product ranges, market fragmeniation (mass-customization) and incrcasing compctition through service differentiation [5]. These it a is "re increasing th" importance of logistics performance in marketing products. Because of this, providing the right customer service level through integration of marketing and logistics is a condition to gain and maintain a competitive edge in many markets

Having said that customer service is increasingly important, writers also pay attentio so to the design of a customer service system For example. Christop'rer [6] identifies six stages in de. signine a service system (see Fig. 1 ). In thrstages majer attention is directed at finding out the service requirements of customers. Stages I, II and III concern market research to identify key elements of sustomer service and their relative importance of different customer groups in order to be able to segment the market on service criteria Typical research techniques during these first stages would be expert opinion methods and customer surveys asking the customer to name and/or rank service elements As suppliers can probably not fulfil all customer wis', as they will have to make trade-offs The service levels must be set based on the relauve importance of the kcy service elements

However in designing customer seivice systems in pract:cal situations two problem areas can be identified

- Unclear market information Information gathered during the first three stages is uftein ambiguous and unquantufied. For example, much depends on who answers the survey questions within the customer organisation, the bayer or the production manager or someone else

- Internal trade-offs Service level decisions are ixade to optimise local costs only, both at sup$n l_{1}=$ and customers

Tro consequences of these problems are that is man situations, customers are offered ether ton much or too little servici, Overall cost-efficrency is low

In this paper the above stated problems will be 


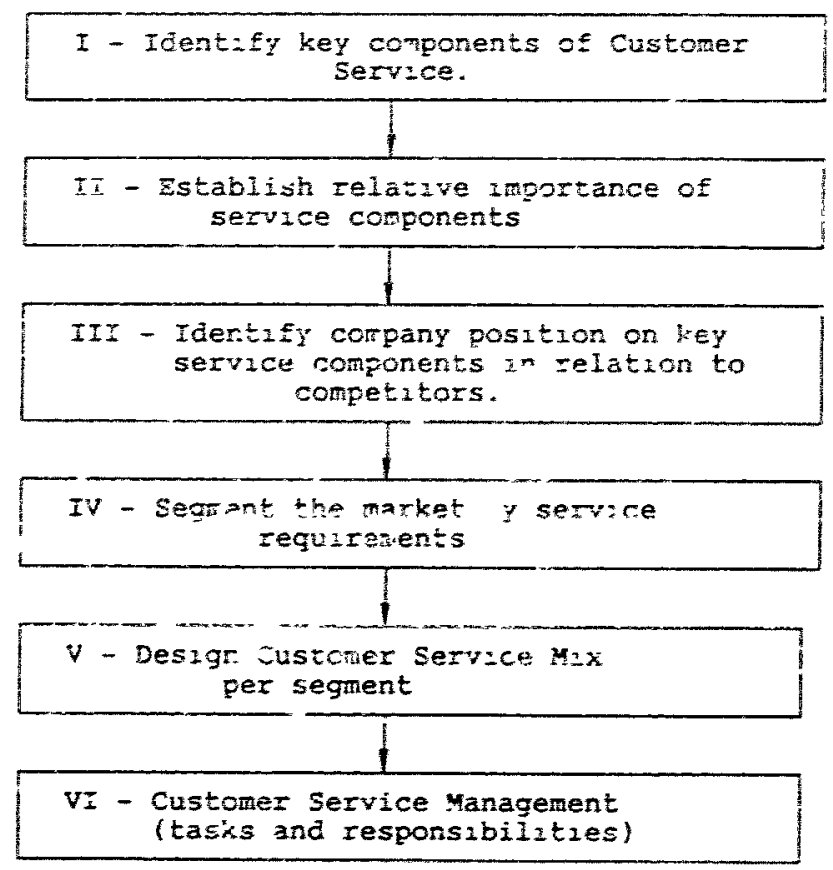

Fig I Stages in designing a customer service ststem

further discussed. We will describe the general cost structure of customer service. To imprcve service levei decisions, an overall cost approach will be introduced. As iso. the use and applicability of this overall cost approach will be discussed.

\section{The costs of customer service}

Customer service should aim at customer satisfaction through fulfilment of customer demand. Without adding another definition to an already long list [7], this text will follow Christop'yer and cons.der customer service as: "the output of the logistics system touards customers." Customer service levels determine the amount of service provided to the customer. For individual service items these levels can be quanthied or measured, for example 24 hour deliver. ies or $95 \%$ reliabulity of deliveriec. The genera! service level can be itscribed as the total "amount of service" on the individual items.

In this text we suggest an approach of making service level decisions considering overall costs. thereby providing the designer of the service sy- tem better insight in the added value of the service tc the customer. To use an overall cost-approach in sernice level decisions one must know the relition between service and costs for both supplier and customer. First $x$ wiil discuss these telations for suppher and custome- individually. The cost-curves are depicted in Fig. 2.

Supplier costs. At short or medium long term. every supplier is capable of offering a certan service level which fits its organication. This seibec level depends on the kund of logistic facll. lies and management ystems the supplier has

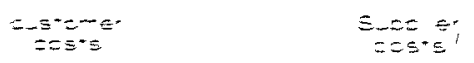

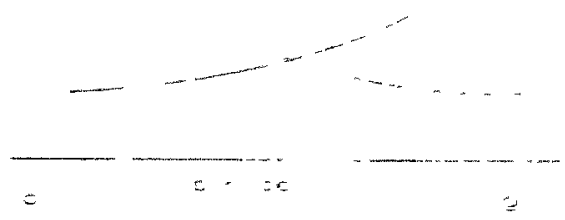

Fig. 2. Costecurts 
invested in. Offering service below th:s lev el will result in only a small decrease in costs. because investments are already made and people and systems are adapted to a higher service level Also, offering servive above this leve will trure than proportionally increase the costs dua to dmmishing economies of scate. Therefore. in many situations overall cost-CH. will be similar to the urric ia Fis. 2.

Customer cosis The sertice offered to the cus. tomer should result in (percerved) adued "alue to the customer. For the cusianes, the service of fered has a diminishung marginal "alue. The customer organisation requires a certain level of service. Being supplied below that lcvel will indure far higher costs, while being suppled above that service level will only lead to smail benefits Also here we consiúci nily shóni or mediun term consequences

The structure , , e service cost-curves is illustrated in box 1 by a quantified example on ordersizes.

It must be remarked that both customer and supplier cost-curves are not always smoothy shaped like in Fig. 2. Cost-curves of individual sarvice clements can have break-points, increasi to a cortain maximum or be strictly proportional to the level of service for examre. increasing service through shoritening delvery lead-times will for the sup, ter lead to morer, i st charges with breakinomin at the lead-times wh. an extra warehouse ciose- 10 the customers is needed In many sitiatsus howe : : general cos: curves will be sima. $r$ to the curves on Fig

This cost-structure of service, with hiph chstomer cost at low servic: levels and high supplus cect at high service levels, means that costwintcient service levals can oniy be vitanned when ?n overall cost-apuroach is used To set the service levels. quanified information un hoth supplist and customer costs must be avalable With it, s cost-framework the canlier mentroner problem areas can be discusared

\section{Problems in sct inf sartae les ols}

\section{Cnokgenorket lofirmatum}

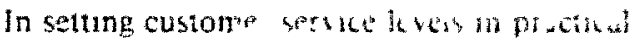
sttuations the two pro atems of undear narket information and internal trace-offs tale been identified The problem area of not krowing what customers really wan' can te drided in two parts

Unquanthed mfon main From the cost-

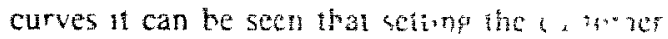
service levels requires information $n \pi_{\text {w }}$ unit on what service the custumets kant bu ass how much they want of at The results of 5 .tom surve;s are often not wery clear about $\mathrm{n}_{4}$ ? $\mathrm{An}_{\mathrm{n}}$

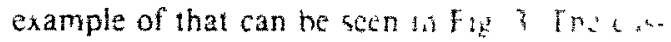
tomers of a company have anked indati a service elements on a sale from if 4 lnc d:erage rankings are presenter as the recults of the survey. These recults do not tell much about the level of. for example delwery thability Another example is that both 24 hour and 48 hour may be consudered shat ifau-imes while 24 hour delivery whll result in much higher cosis for the supplier

Ambiguly of information the information som market $r$. 'r. may nol always be clear Customers may seem to want short deliter: lewd umes while what they really want are reliable ce-

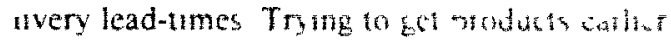
can be a way of making sute sou h we them on ume Another issue in this is the int, changeabl1ty of service aspects and price $M$ n: buyers dre prepared to anapt th ar serice re utremen $_{5}$ if this results in price reduction The aportans of

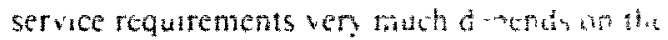
hind of products bough $|8|$

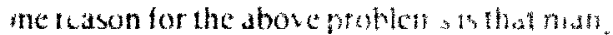

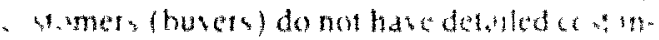

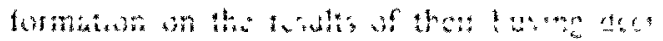
sons The value of the stricte of efed cantion

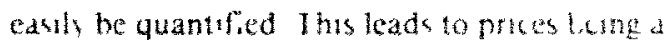
"en important tacior in buyng de shor', aht is

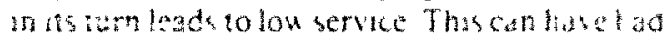

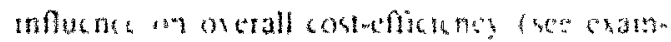
ple. ondermbe 2x pallets)

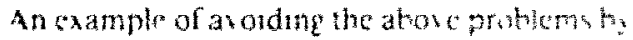
using overall cost information can $h$ foumd in food-retaling stludtons where buters and solsts

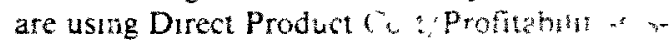
lems (DPC/DPP) These kird of (softhe

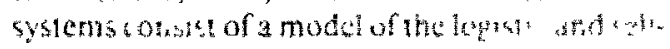

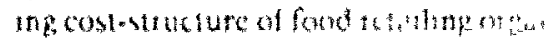

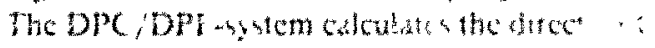
and resulung profits of butheg proctures of .... 


\section{Bor 1. Example}

Constder Iwo compantes Metrom, a produc-

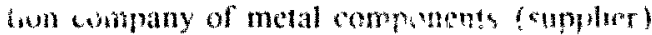
and the Machne Manuiacturng Fatury IN MF (customer) Components are delivered irom tnck to MMF once a month in fill :rie:n-hads of 22 pallots $(2500$ trmes per pallet), free of charge. The delivery lead-tume is one day.

In the customer costs the following variables involved with the present way of ordering an be described.

co wordeng cos 1 per order $=\$ 50$

, - - iretio of hol ling anventory in percentage of iswentory value (interest + space costs).

$\mathrm{TCC}=$ Tolal yedrly cosis of the customer lorder ing + nventory rosts?

$X=$ order-Size in pallets $(22$ in the present stuation).

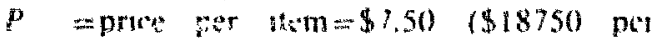
pallet).

Inv = Average Inventory value

TCC depends on the number of days between placung two orders rotal production days per year is 250 The delucry lead-umi whll not change, therefore safety stock is not constoered

$\mathrm{TCc}=\frac{250}{X} * \mathrm{CO}+\ln \mathrm{v} * 1$

$$
\begin{aligned}
& =\frac{250}{X} * 50+(05 * 18750 * X) * 015 \\
& =\frac{12500}{x}+1400 * x
\end{aligned}
$$

Minımal costs

$$
\begin{gathered}
d(T C) \\
d(A)
\end{gathered}-0 \Rightarrow X=\frac{12500}{1400} \approx 3
$$

$\operatorname{TCc}(3)=8370$

$\operatorname{TCc}(22)=31370$

Ordenng every three days would mean a $75 \%$ crists reduction for MMF.
He tesulting costs at the supplict Meteom can he calculated as follows

si sales cous per ordat $=\$ 25$

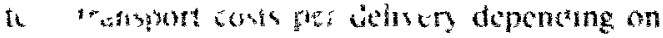
order-51/t:

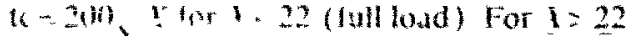

trimsmon costs a re full load $+300,(1-22)$.

ISc total yearly suppiner costs (sales + transport costs :

$$
\begin{aligned}
\mathrm{TSc} & =\frac{250}{Y} * 1 \mathrm{c}+\frac{250}{Y} * \mathrm{sc} \\
& \left.=\frac{250}{X} * 200\right) 1+250.25 \\
& =\frac{50000+6250}{1}+\frac{1}{1} \\
& 1011.22
\end{aligned}
$$

From this costs function it is clear that to minimuse supplier costs $A$ shouid be 22 ( = fuil load).

Metcor and MMF decide to look at the total chan costs $(\mathrm{CHC})$ and try to munumise these.

$\mathrm{CHc}=\mathrm{TCs}+\mathrm{rSc}$

$$
=\frac{12500}{x}+1400 * x+\frac{50000}{\sqrt{x}}+\frac{6250}{x}
$$

Optimal costs.

$$
\begin{gathered}
\mathrm{d}(\mathrm{CH}) \\
\mathrm{d}(\mathrm{V})
\end{gathered}=0 \Rightarrow 1=8
$$

CHc(3) $=8,370+30,950=\$ 39.320$

$\mathrm{CHc}(8)=12,760+18,460=\$ 3 !, 220$

$\mathrm{CHc}(10)=15,250+16,436=\$ 31,686$

$\mathrm{CH}(22)=31,870+10,940=\$ 4,2 !$,

From the results listed above the two companes could see what would be the best way to dehver the components. It was decided to deliver the components in 2-week quantities for that would make easier planming than delivering every 8 days without much extra cost. 


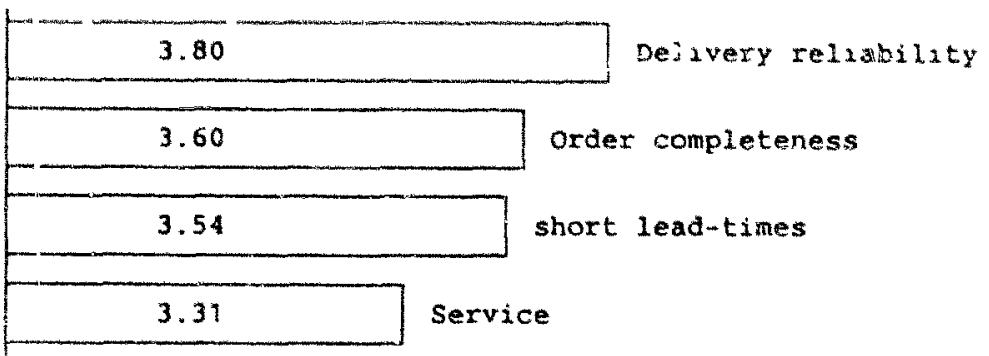

Fig Importance at sorvice elements (example)

tain quality at a certain service level based on logistucs pres. charatternstucs and poces 19 j Thw can change buyers from using cross margin in buying decisons to using information on direct profit and costs it musi se remurked that presuntly these DPC/DPP-systems are mainly used by food vendors and retaulers DPC/DPP. systems have been developed for these stuations only But aiso w other commercual relationships this approach can be useful. This requires a costframework, adapted to the characteristics of inunuinal customer service clemerits

\section{$3 \pm$ Lordi cost cptimisation}

The earlie: sygnalled trend of markef fragmentating reaures suppiners in gdapt their service to each individual customer. In general every customer want; its surpliers to offer the highest service and quality at the lowest price As this is impossible. trade-offs have to be made In most situations trade-offs are miade to local costs if overall cost information is not avalable the servtoe levals will be set enther to a supplier or cus-

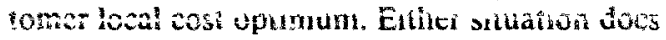

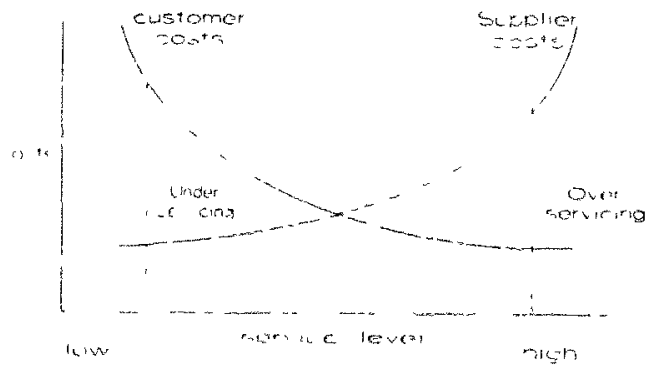

$\tau_{1}+$ inder-servicing and over-serveing not often lead to an overall cost opumum as can be sen from $\Gamma$ to 2 and the example the sup plier cost optanum is at a very low service level where the overall costs can be ioweted by increasing service levels. This situation can be describea as "under-servicing" (see Fig 4). The customer cost optumum is reached at a high level of service which leads to "over-servicing". In that situation, lowering the service levels will lead to lower overnll costs (see Fig. 4).

\section{The werall costapproach and other service level aspers}

The overall cat optumus is not the only as pect in the process of setting the service levuls There can be other aspects whech also lave tr fhience on the service level decision. Still, when suppliers are over-servichis their customers, in skould be known what the extra cests are to monnor the success of the strategy In this section the important aspects of the market...\% strategy and prece will shortly be discussed.

\section{4 i Murketrig sinatgy}

The service level decision is considered a tacucal decision which must be taken in accoldance with the overall marketing strategy $[2,10]$ The marketing strategy determunes for example to compeste on price or selvice asd qually The strategy can be the reason for a supplier to positron his customer service at a cost inefficient level An example of such a strategy would be a situa. tron where higher service is use to penctrate : market or increase the market-share to get a beitri strateguc postion on a market The extra costs 


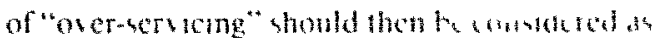
markstung. costs

\section{PMar}

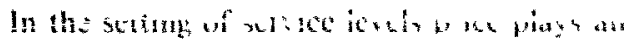
impontant role $A$ price reduction can be an incenture for the customes to lonsen them sertice denands and thereby letting th" suppler set cutower servie at a more rofi-enticient level Aiso. customers which allow higher prices for evtra service may iead to a supplier morasing the service level.

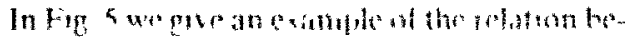
tween cons of service and pice the soppler h been pushed thto a sluatron of over-s, vicing at level $H$. When service requirements ate decreased to level $1 /$ the supplicr can save $C$ on his costs Due to the structuic of service conts, the supplier's savings are higher than the increase of costs $a^{+}$at the customer The satung of the sup. plier determme the possble price reduction If all suving are mat int the price reduction, the shift is financially neutral to the sunplier. How ever. the price reduction may lead to a growing marketshere and thereby increased revenue for the supplier

An important factor in this is the price elasticity of the market In geficiai pun cisicity depends on the homogeneity of the product (and service) On a homogeneous market, denand will have a high price e'astieity. Increasing the puce will lead to lower stes in this case, only if customer service can move a supplien sway from the homogeneity, the increased costs of higher service can be compcisdated for by a higher price without loosing market share in heterogeneos's

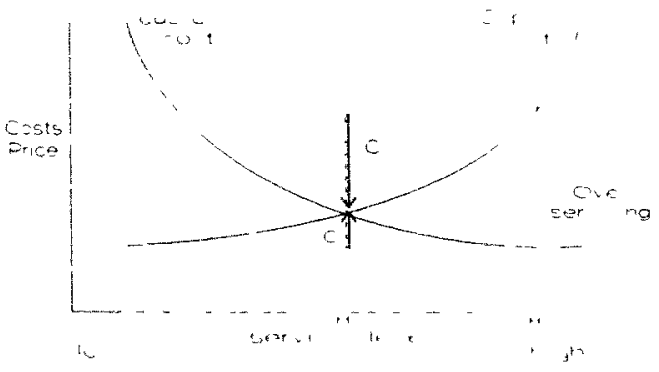

Hig 5 Priks and xirues costs

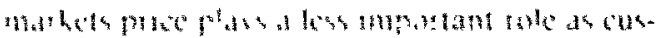

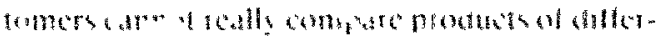

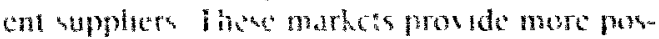

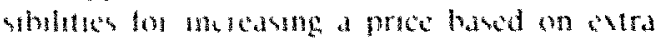
$3018146^{2}$

\section{5. l sing this ov erall cow approach}

Howevel important, we do not want to suggest that using the overall cost-approach will easily solve all service level problems In this section we wnil discuss sone of the problems and condr- on of using the annroach

\section{$\therefore$ anchums}

Ubtanng an overall cost optimum is not al. ways an achevable strategy in every suppliercustomer tolationshy I wo important condr.

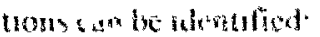

-Mutud mitetests

A first imporent aspect is the mutual intorest companies must have in mantaning a good relatonshp. Obtaning the overall cost optritum will often require some changes in the supp $p^{\text {' }}=$ customer relationship When there is no mutud interest in the relauonship, he companes will not be willing to make any adaptations

-Avalability of cost infornation

If companses do not have an open relatıonship in which service matters can be discussed, the right service levels cannot be obtaned In many situattons both customers and suppliers are pot at all willing to provide each other with cost informaton Companies are afraid of jeopardising their commercial interests by giving away too much information. This protection of information from a commercial point of vew, is a major barrier in many sttuations of tunıng serve. Icyuirements.

Still, even if the above conditions are not fulfilled, the overall cost-approach can be valuable in settıng the service level.

\section{2 Suppler-customer ielationship}

To get an idea of how the cost approach can be used in different stuat.ons we identify three customer-supplier relditons

-ircuciental:

-Repeated buying: 
- Co-makersho

Fach of these relutwons regures another wath of obtamug and using (overal') cost information

\section{Inctidental}

An incic̀entar reiationsthp bueween two compantes is the situaticn in which customers buy on! once or twice from the same supplier The sapplier has a contunuously changing group of customers, or customers buy at a ring low hiequency. for example su phers of investment goods (production mactinicry or large office cquipment) to industrial custome's Customer cost curves cannot be identified Sering the level of service is an internal matter of supphers as they cannot adap then service levels to an ever changing group of customers The ievel of service in this situation depends manly on the marketing strategy and the conpentuve sttuation. Logisfe manigement mest try to mununse costs ai bie setvice level set Adapting the service level for individual customers will result in significantly higher cosis.

în this stuation tne (overail) cost-approach is used for internal coxts only to indie ate the level of service appropriate to the onganisation's facithes. If this level is significantly different from the service level determıned by the markeing strategy. ether the company should mvest in new facilues and equipment or change its strategy.

\section{Repeated buing sthation}

The situation of repeated buying occurs when a large group of customers frequently buys products from the same supplier. Typical products for this situation would be purchase parts and raw materials. Relations between customer and suppiser iast for a longer period In this situation it is very well possible to obtain information on both supplier and customer costs Customer surveys should result in quantıfied customer service information segmentation of customers will be necessary. This requires a good marketıng research program as customers are not always willing to make this information avallable to suppliers A more analytucal way to obtain insight in customer cost curves is to design and/or use a DPP/DFr-system. The system can be filled with

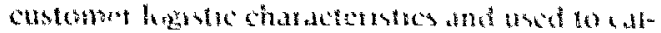
culat the cost consequences of the customer service offecd if customers are unable to guantify cosis themselves. DPP/DPC - systems can also be used to convince customers of the valu. added through servec [9] As both cus tomer(segmeny) and suppluer costs an quant1fied, service levels ca be set as close as possible to the overail cost mmmum in each segment its overall cost-approach becomes an integrated part of the customer service design system

$$
\text { "1) maker shp rlatim }
$$

A co-makershp relation is where suppher and customci are work ring howartis a commun god, fully using each others potenual while kecpug separated financul ownershe stuuctures. Thrs relation occus in a situation with a high mutual dependence of supplier and customer The cuswher can be dependent because alternative supphess are hard to find Suppliers may experience dependence because the customer is tesponsible for a large part of totdi sales volume in co-makership, openness is the very nature of the velaton Detaled cost information is passed on through the channel in both directions Costcurves are clea for both sides. In this sifuation the overall cost-apptoach must be used to obtam the rignt ser vice level.

When cests of both customer and suppl:er are quantified, it may be possible to adapt facilities or procedures to lower the cost curves (In a case situation we studied, it turned out to be possible to lower the supplier cost-curve through a very small adaption in order procedures. The result was higher service at lower overall costs) The overall cost-approach is a major tool in bulding a co-makership relation

\section{Conclusions}

Although an overall cost opumum cannot be achieved in every situation, the cost-approach does provide a better view on the results of service level decisions Not using quantified information or not discussing service levels at all can easily lead to over-servicing or under-servicing. As has been stated, the avalability of cost information can be a big piohlem Commerciel : ter- 
ests seen to be more important than ovetall cost minimisation Using the ovetall cost-approach requires a new way of customers and supplizes dealing with each-other sales:stopit should be able to bring wis matter of service levels, even in sruations where customers oniy sient to be inarested in low prices More research will be directed at how to evercome the commercial barriers in obtaining cest information When this kind of information is avalable, the service level can be set to minimise cham costs Minmai chain costs provide both customer and supplier with better opportunities to compete on their markets.

\section{Acknowledgementis}

Hereby we kindly thank prof. dr. $H$ W.C van der Hart and prof. dr J. Wyngaard of the Eindhoven University of Technology and three anonymous referees for then constructuve comments on earlier versions of this tex.

\section{Fefierences}

1 Christopict. M, 19:5 Reaching the customer Strategics for marking and customer service Journal of Markeung Mgt, 2(1) $53-7$ !
2 Lamber i) M Ilarangon To 1989 Establwhing

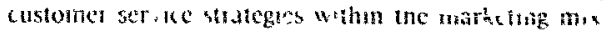
More empirsal es idence lournal of Busmess Logistica $10(2)+4-60$

3 De Valn, M JM and Egumk, DS I 1987 Marketing en Logstick Tidschrift toot Inkoop en Logustick 34

4 Voorhess, R D and Coppen, II Matheng-logistucs opportunue for the lon, lourua of Busmess Strattas. 70 ? 33-30

5 Yr Goor A <. 1988 Raakvlakken tursen proc iktleRaragubar ixoon con fvsieke distributie in A Bosman and $G \bar{S}$ Eyzenga (eds ) Plannmb ta Produkise en Logistuek Wolters-Nordhoff Groningen Cnapter II

6 Chistopher, M. 1985 The Strategy or Distribution Management Cower Press London

7 Ronehart $\mathrm{L} M$, Cooper, $M B$ and Wagenhem, G D Furtheng the integration of marketirg and logistics through customer service tn the channel Journal of the vadem of Marketing Science, 1711:63.7!

8 Van Wu k F J A, "986 Samenwerhngurelates tussed andusti cle atnemess en leveranciers Tudschnft voor mark "1my, May 118-136

c Alevinder, J, 1988 Benefits galore from DPP Retal and Distubution managemen, Septenber/October 1417

10 Kotler, $\vec{k}$ Marketıng Management, Analysıs Planning and Control, 4th edition Preis', -Hall, Englewood Chifs, NJ 